\title{
The impact of the type of soil contaminated with heavy metals on the risk of their translocation to the consumption parts of maize ${ }^{1}$
}

\section{Wpływ rodzaju gleby zanieczyszczonej metalami ciężkimi na ryzyko ich przedostawania się do części konsumpcyjnych kukurydzy}

\footnotetext{
*Dr hab. inż. Ewa Stanisławska-Glubiak, prof. nadzw., mgr inż. Sylwia Gołda, Department of Weed Science and Soil Tillage Systems in Wroclaw, Institute of Soil Science and Plant Cultivation - State Research Institute in Pulawy, Orzechowa 61 St., 50-540 Wroclaw, Poland, phone: +48 713638707 , e-mail: e.glubiak@iung.wroclaw.pl,s.golda@iung.wroclaw.pl
}

Keywords: soil contamination, sandy soil, loess, Cd, Pb, Zn, maize, bioaccumulation, translocation, organic matter Słowa kluczowe: zanieczyszczenie gleby, gleba piaskowa, less, Cd, Pb, Zn, kukurydza, bioakumulacja, translokacja, materia organiczna

\section{Abstract}

The purpose of the research was to examine the extent to which the type of soil co-contaminated with $\mathrm{Cd}, \mathrm{Pb}$ and $\mathrm{Zn}$ affected the accumulation and distribution of these metals in maize; a crop that plays a significant role in feeding of animals and humans. Two 1-year microplot experiments were conducted using four types of soils. The soils were as follows: sandy soil with a low content of organic matter (S1), sandy soil of analogical granulometric composition, but with a higher content of organic matter (S2), loess poor in organic matter (L1) and the same loess with its higher content (L2). The differences between the soils in terms of the availability of individual metals for maize and their transport from the roots to the aerial parts were evaluated on the basis of bioaccumulation factors (BF) and translocation indexes (TL). It was found that maize cultivation on the soil poorly polluted with $\mathrm{Cd}, \mathrm{Pb}$ and $\mathrm{Zn}$, regardless of its type, poses the danger of translocation of these metals to the grains in the amounts exceeding the maximum limit in foods. However, the amount of metals accumulated in the grain, as well as in the cobs, do not exclude the use of these plant parts for feed.

(c) IOŚ-PIB

\section{Streszczenie}

Celem badań było sprawdzenie, w jakim stopniu rodzaj gleby zanieczyszczonej łącznie $\mathrm{Cd}$, Pb i Zn wpływał na akumulację i dystrybucję tych metali w kukurydzy jako roślinie odgrywającej znacząca rolę w żywieniu zwierząt i ludzi. Przeprowadzono 2 jednoroczne doświadczenia mikropoletkowe, z użyciem 4 rodzajów gleb. Były to gleby: piaskowa o małej zawartości materii organicznej (S1), gleba piaskowa o analogicznym składzie granulometrycznym, ale o większej zawartości materii organicznej (S2), less ubogi w materię organiczną (L1) i ten sam less z większą jej zawartością (L2). Różnice miedzy glebami w dostępności poszczególnych metali dla kukurydzy oraz ich transporcie z korzeni do części nadziemnych oceniano na podstawie współczynników bioakumulacji (BF) i translokacji (TL). Stwierdzono, że uprawa kukurydzy na glebie słabo zanieczyszczonej $\mathrm{Cd}$, Pb i Zn, niezależnie od jej rodzaju, stwarza niebezpieczeństwo przedostawania się tych metali do ziarna w ilościach przekraczających dopuszczalne zawartości w produktach żywnościowych. Jednakże ilości metali zgromadzone w ziarnie, jak również w osadkach kukurydzy, nie wykluczają możliwości przeznaczenia tych części roślin na paszę.

\section{INTRODUCTION}

Heavy metals in the soil, originating both from natural and anthropogenic sources, can be a threat to the health of animals and people. In the case of translocation of metals from the soil to the food chain, the first link of which is a plant, the key matter is the safety of the edible parts, meant for feed, processing and direct consumption. Excessive amounts of metals in the soil occur mainly in the areas centred around energy, mining and metallurgy industries; however, dust contaminants can be transferred to the regions located far from the industry centres, causing soil contamination with metals to various extents. Highly contaminated soils should be excluded from agricultural production. On low or medium contaminated soils, agricultural production can be performed under the condition of using certain species limitations and periodical control of the amounts of metals in consumption parts of plants [Kabata-Pendias et al. 1993]. Maximum levels of some metals ( $\mathrm{Pb}, \mathrm{Cd}, \mathrm{Hg}, \mathrm{As}$ ) were determined for certain products of plant origin meant for consumption [Rozporządzenie... 2003]. The ability to uptake excessive amounts of metals from the soil by crops depends on the characteristics of the plant species. Different species of plants developed various physiological barriers and defense mechanisms limiting the uptake of metals and their detoxification in tissues [Seregin et al. 2004, Seregin, Kozhevnikova 2005, Figueroa et al. 2008]. The amount of the metals absorbed by plants is determined by properties of these metals [Burló et al. 1999] and interactions with other elements and soil pollutants [Shanker et al. 1996, Cui et al. 2004, da Cunha, do Nascimento 2009, Zhang et al. 2009]. Some physicochemical properties of the soil may result in the retention of metals in the soil, which limits their uptake by 
plants. Retention of metal ions in the soil occurs mainly through the processes of adsorption, surface precipitation and fixation. The main connections involved in the adsorption of metals in the soil are primarily inorganic colloids, such as clay minerals, metal oxides and hydroxides, carbonates and phosphates, as well as colloidal organic matter and micro-organisms, such as algae and bacteria [Bradl 2004]. Adsorption of metals on the clay minerals increases in the following order: $\mathrm{Mn}<\mathrm{Pb}<\mathrm{Cd}<\mathrm{Zn}<\mathrm{Cu}<\mathrm{Ni}<\mathrm{Cr}$ [Abollino et al. 2003]. The main parameters affecting the adsorption of metals in the soil are $\mathrm{pH}$, texture of the soil, organic matter content and its structure [Kalbitza, Wennrich 1998, Peralta-Videa et al. 2002, Szabó, Czellér 2009]. Low pH and a small fraction of clay and organic matter in the soil increase the availability of metals to plants [Kabata-Pendias 2004, MacLean 1976, Martínez, Motto 2000, Skłodowski et al. 2006].

Metals absorbed by the plant are accumulated in the tissues and organs to varying degrees. Most species retain metals in the roots [Shanker et al. 1996, Seregin et al. 2004, Suthar et al. 2014, Shao et al. 2007], but there are cases where a higher metal content was found in the aerial parts than in the roots [Cao et al. 2007, Szabó, Czellér 2009].

The aim of this work was to verify to what extent the type of soil co-contaminated with $\mathrm{Cd}, \mathrm{Pb}$ and $\mathrm{Zn}$ affects the accumulation and distribution of these metals in maize, which plays a significant role in human and animal nutrition.

\section{MATERIALS AND METHODS}

Two 1-year experiments with maize were carried out in concreteframed microplots with the dimensions of $1 \times 1.2 \times 1 \mathrm{~m}$. The microplots filled with sandy soil and loess, which 10 years earlier had been contaminated with metals $(\mathrm{Cd}+\mathrm{Pb}+\mathrm{Zn})$ to a low or medium level according to the IUNG classification [Kabata-Pendias et al. 1993]. Two years before the cultivation of maize, on the part of the plots, garden peat with a specific gravity of $0.25 \mathrm{~kg} \cdot \mathrm{I}^{-1}, \mathrm{pH} 6.5$, $\mathrm{OM}-45.2 \%$ was introduced into the soil, at a dose of $40 \mathrm{I} \cdot \mathrm{m}^{-2}$. In this manner, two sandy soils were obtained with the same degree of metal contamination, but differing in organic matter content, as well as two analogically varied loess (Table 1).

The experiment was conducted in the complete randomization design, in four replications. Maize plants were sown in May 2011 and 2012, leaving eight plants in each plot after the thinning. Pre-sowing fertilization was used with $\mathrm{N}-4.0, \mathrm{P}-2.4$ and $\mathrm{P}-9.6 \mathrm{~g} \cdot \mathrm{m}^{-2}$ and the top dressing with $\mathrm{N}-8.0 \mathrm{~g} \cdot \mathrm{m}^{-2}$. In the periods of drought, the plants were watered. Plants were harvested at the stage of harvest maturity by cutting the entire aerial parts from each plot and dividing them into ears and straw. The straw was composed of stems with leaves. Then, the ears were separated into cobs and grain. The roots were dug up, brushed off from the remaining soil and washed on a sieve with distilled water. All parts of the maize were dried at $60^{\circ} \mathrm{C}$. Then, it was ground into a fine powder and the samples were taken for chemical analysis.
The concentrations of heavy metals in samples of plant, after ashing in a muffle furnace at $500^{\circ} \mathrm{C}$, and dissolved with $20 \%$ nitric acid (PN-R-04014: 1991), was determined by atomic absorption spectrometry of atomization in the flame (FAAS). All analyses were performed in Central Laboratory of Institute of Soil Science and Plant Cultivation in Puławy, certified by Polish Centre of Accreditation (certificate no. AB 339) according to PN-EN ISO/IEC 17025.

The soils were determined for $\mathrm{pH}$, total organic carbon (TOC), total content of $\mathrm{Cd}, \mathrm{Pb}$ and $\mathrm{Zn}$, and texture (Table 1). The $\mathrm{pH}$ was measured potentiometrically in $\mathrm{KCl}$ solution (ISO10390: 2005), TOC by the Tiurin's method using potassium dichromate (PN-ISO14235: 2003) and texture by an aerometric method (PN-R-04033: 1998). Total contents of $\mathrm{Cd}, \mathrm{Pb}$ and $\mathrm{Zn}$ were determined by FAAS after mineralization in aqua regia.

\section{RESULTS AND DISCUSSION}

From the soil co-contaminated with $\mathrm{Cd}, \mathrm{Pb}$ and $\mathrm{Zn}$, maize accumulated metals depending on its texture and organic matter content. Based on the bioaccumulation factor (BF), it found that, in general, the plants accumulated the most metals from the sandy soil with low organic carbon content (S1) in the order of $\mathrm{Zn}>\mathrm{Cd}>\mathrm{Pb}$ (Table 2). The metals were accumulated in such an order both in roots and in aerial parts - straw, cobs and grains.

Maize accumulated lower amount of metals from the loess poor in organic matter (L1) than from sandy soil S1. BFs on L1 were lower in comparison with the soil S1 and occurred in the following order: $\mathrm{Cd}>\mathrm{Zn}>\mathrm{Pb}$ for the roots and straw, while in the cobs and grain in the order of $\mathrm{Zn}>\mathrm{Cd}>\mathrm{Pb}$. A similar order of bioaccumulation of metals in aerial parts of maize was reported by other authors [Jasiewicz et al. 2008], while under the conditions of "non-contaminated areas", bioaccumulation of metals in grain and aerial parts of maize occurred in the order of $\mathrm{Zn}>\mathrm{Pb}>\mathrm{Cd}$ [Lavado 2006].

The biggest difference between soil S1 and L1 occurred in the bioaccumulation of $\mathrm{Zn}$ and $\mathrm{Pb}$ in maize. BFs for $\mathrm{Zn}$ in the soil $\mathrm{L} 1$ were by about $85 \%$ lower compared with $\mathrm{S} 1$, and the $\mathrm{BFs}$ for $\mathrm{Pb}$ by about $75-85 \%$ lower, depending on the part of maize. Cd accumulation in the soil $\mathrm{L} 1$, as compared with $\mathrm{S} 1$, was only by about $30-40 \%$ lower in the roots, straw and cobs while the grain is better protected than the other parts of the plant. BF for the grain in L1 soil was approximately $75 \%$ lower compared with S1.

In the literature, we can find reports on the impact of humic substances on the bioavailability and phytotoxicity of some metals [Lamelas et al. 2005, Kungolos et al. 2006, Wu et al. 2002, Kang et al. 2011]. In the studies carried out on two soils with the same granulometric composition, but differing in organic matter content, there was a decrease in Cd concentration in maize and other plants growing on the soil richer in organic matter [MacLean 1976]. In the present study, the addition of organic matter to the sandy soil and loess modified the availability of metals to plants and changed their bioavailability (Table 2 ). On sandy soil S2, there was a decrease in the accumulation of $\mathrm{Cd}$ and $\mathrm{Zn}$, and to a lower

Table 1. Physical and chemical properties of the upper layer $(0-20 \mathrm{~cm})$ of the experimental soil - average of the years of 2011 and 2012

\begin{tabular}{|c|c|c|c|c|c|c|c|c|}
\hline \multirow[t]{2}{*}{ Soil } & TOC & SF I & SF II & SF III & \multirow{2}{*}{$\mathrm{pH}$} & $\mathrm{Cd}$ & $\mathrm{Pb}$ & $\mathrm{Zn}$ \\
\hline & \multicolumn{4}{|c|}{$\%$} & & \multicolumn{3}{|c|}{$\mathrm{mg} \cdot \mathrm{kg}^{-1}$} \\
\hline Sandy soil (S1) & 0.34 & 90 & 8 & 2 & 5.3 & 1.39 & 341 & 484 \\
\hline Sandy soil (S2) & 1.26 & 90 & 8 & 2 & 5.5 & 1.78 & 363 & 627 \\
\hline Loess (L1) & 0.50 & 27 & 63 & 10 & 5.8 & 6.86 & 956 & 2906 \\
\hline Loess (L2) & 1.85 & 27 & 63 & 10 & 5.8 & 8.02 & 900 & 3040 \\
\hline
\end{tabular}

SF I - soil fraction $2.0-0.05 \mathrm{~mm}, \mathrm{SF}$ II - soil fraction $0.05-0.002 \mathrm{~mm}, \mathrm{SF}$ III - soil fraction $<0.002 \mathrm{~mm}$. 
Table 2. Bioaccumulation factors of metals on co-contaminated soils with $\mathrm{Cd}, \mathrm{Pb}$ and $\mathrm{Zn}$

\begin{tabular}{|c|c|c|c|}
\hline \multirow[b]{2}{*}{ Soil } & \multicolumn{3}{|c|}{ Bioaccumulation factor (BF) } \\
\hline & $\mathrm{Cd}$ & $\mathrm{Pb}$ & $\mathrm{Zn}$ \\
\hline & \multicolumn{3}{|c|}{ Roots } \\
\hline Sandy soil (S1) & 2.824 & 0.573 & 3.514 \\
\hline Sandy soil (S2) & 1.238 & 0.321 & 1.537 \\
\hline Loess (L1) & 1.488 & 0.147 & 0.676 \\
\hline \multirow[t]{2}{*}{ Loess (L2) } & 0.568 & 0.107 & 0.541 \\
\hline & \multicolumn{3}{|c|}{ Straw } \\
\hline Sandy soil (S1) & 0.322 & 0.032 & 1.177 \\
\hline Sandy soil (S2) & 0.298 & 0.032 & 1.135 \\
\hline Loess (L1) & 0.224 & 0.009 & 0.176 \\
\hline \multirow[t]{2}{*}{ Loess (L2) } & 0.104 & 0.007 & 0.211 \\
\hline & \multicolumn{3}{|c|}{ Cobs } \\
\hline Sandy soil (S1) & 0.079 & 0.007 & 0.527 \\
\hline Sandy soil (S2) & 0.038 & 0.002 & 0.318 \\
\hline Loess (L1) & 0.05 & 0.001 & 0.063 \\
\hline \multirow[t]{2}{*}{ Loess (L2) } & 0.015 & 0.001 & 0.062 \\
\hline & \multicolumn{3}{|c|}{ Grain } \\
\hline Sandy soil (S1) & 0.039 & 0.001 & 0.099 \\
\hline Sandy soil (S2) & 0.03 & 0.001 & 0.066 \\
\hline Loess (L1) & 0.009 & 0.000 & 0.014 \\
\hline Loess (L2) & 0.005 & 0.000 & 0.014 \\
\hline
\end{tabular}

degree, of $\mathrm{Pb}$, compared with $\mathrm{S} 1$. On the loess $\mathrm{L} 2$, in relation to the $\mathrm{L} 1$, there was a significant decrease in $\mathrm{Cd}$ accumulation, and to a smaller degree, of $\mathrm{Pb}$ and $\mathrm{Zn}$. It should be noted that the addition of organic matter to the loess was more effective in reducing the accumulation of $\mathrm{Cd}$ than its addition to the sandy soil.

The level of the studied metals in maize, regardless of soil type, was the largest in the roots, next in the straw and cobs, and the smallest in the grain (Tables 3-5)

However, the concentration of $\mathrm{Pb}$ and $\mathrm{Cd}$ in the grain exceeded the maximum limit of these metals $\left(0.20 \mathrm{mg} \mathrm{Pb} \cdot \mathrm{kg}^{-1}\right.$ and $0.03 \mathrm{mg}$ $\mathrm{Cd} \cdot \mathrm{kg}^{-1}$ ) in plant products intended for human consumption [Rozporządzenie et al. 2003], while not exceeding the standards for feed (respectively, 10 and $0.5 \mathrm{mg} \cdot \mathrm{kg}^{-1}$ ) both in the grains and cobs [Kabata-Pendias et al. 1993]. Zn content in grain and cobs also did not exceed the maximum tolerable level in the feed according to the U.S. standard, which is $500 \mathrm{mg} \cdot \mathrm{kg}^{-1}$ for cattle [U.S. NRC, 2000]. According to Polish standards, which, without specifying particular groups of animals, established the tolerated level of $\mathrm{Zn}$ at $100 \mathrm{mg} \cdot \mathrm{kg}^{-1}$ [Kabata-Pendias et al. 1993], only the grain met the requirements.
The ratio of the metal content in the aerial parts of maize to their contents in the roots expressed with translocation index (TL) was dependent on the type of metal. Regardless of the type of soil, the highest amount of $\mathrm{Zn}$, and next of $\mathrm{Cd}$ were translocated to the aerial parts of the plants meant for consumption by animals and humans (Tables 3 and 5), while $\mathrm{Pb}$ remained mostly in the roots (Table 4).

The addition of organic matter to the soil changed the distribution of $\mathrm{Zn}$ in the plant to some extent. TLs in the soil S2 compared with S1, and in the soil L2 compared with L1 were slightly higher, indicating an easier translocation of this metal to the aerial part of the metal in the soil with higher organic matter content. The same phenomenon was observed for $\mathrm{Cd}$, but to a lower extent than in the case of $\mathrm{Zn}$. There is some contradiction here as on the one hand, organic matter limited bioaccumulation of $\mathrm{Zn}$ and $\mathrm{Cd}$, but on the other hand, facilitated the translocation of these metals to the aerial parts. This may be related to the fact that the macromolecular organic compounds reduce the mobility of metals in the soil, while low-molecular fractions facilitate their uptake by plants through metal complexation [Karczewska 2008].

Table 3. Cd concentration in different parts of maize - the average of the years 2011 and 2012

\begin{tabular}{|c|c|c|c|c|c|c|c|}
\hline \multirow[t]{2}{*}{ Soil } & Roots & Straw & Cobs & Grain & \multicolumn{3}{|c|}{ Translocation index (TL) } \\
\hline & \multicolumn{4}{|c|}{$\mathrm{mg} \cdot \mathrm{kg}^{-1}$} & Straw & Cobs & Grain \\
\hline Sandy soil (S1) & 4.01 & 0.43 & 0.11 & 0.05 & 0.11 & 0.03 & 0.01 \\
\hline Sandy soil (S2) & 2.25 & 0.52 & 0.07 & 0.05 & 0.23 & 0.03 & 0.02 \\
\hline Loess (L1) & 10.2 & 1.52 & 0.34 & 0.06 & 0.15 & 0.03 & 0.01 \\
\hline Loess (L2) & 4.55 & 0.84 & 0.12 & 0.04 & 0.18 & 0.03 & 0.01 \\
\hline
\end{tabular}


Table 4. $\mathrm{Pb}$ concentration in different parts of maize - the average of the years 2011 and 2012

\begin{tabular}{|c|c|c|c|c|c|c|c|}
\hline \multirow[t]{2}{*}{ Soil } & Roots & Straw & Cobs & Grain & \multicolumn{3}{|c|}{ Translocation index (TL) } \\
\hline & \multicolumn{4}{|c|}{$\mathrm{mg} \cdot \mathrm{kg}^{-1}$} & Straw & Cobs & Grain \\
\hline Sandy soil (S1) & 203 & 10.9 & 2.34 & 0.335 & 0.05 & 0.01 & 0.00 \\
\hline Sandy soil (S2) & 117 & 11.5 & 0.71 & 0.335 & 0.10 & 0.01 & 0.00 \\
\hline Loess (L1) & 140 & 8.15 & 0.54 & 0.335 & 0.06 & 0.00 & 0.00 \\
\hline Loess (L2) & 95.5 & 6.53 & 0.71 & 0.335 & 0.07 & 0.01 & 0.00 \\
\hline
\end{tabular}

Table 5. Zn concentration in different parts of maize - the average of the years 2011 and 2012

\begin{tabular}{|l|c|c|c|c|c|c|c|c|c|}
\hline & Roots & \multicolumn{2}{|c|}{ Straw } & \multicolumn{2}{|c|}{ Cobs } & \multicolumn{3}{c|}{ Grain } & \multicolumn{3}{c|}{ Translocation index (TL) } \\
\hline Soil & \multicolumn{4}{|c|}{$\mathrm{mg} \cdot \mathrm{kg}^{-1}$} & & Straw & Cobs & Grain \\
\hline Sandy soil (S1) & 1700 & 556 & 253 & 46 & 0.33 & 0.15 & 0.03 \\
\hline Sandy soil (S2) & 970 & 703 & 198 & 40 & 0.73 & 0.20 & 0.04 \\
\hline Loess (L1) & 1958 & 504 & 181 & 41 & 0.26 & 0.09 & 0.02 \\
\hline Loess (L2) & 1645 & 642 & 190 & 41 & 0.39 & 0.12 & 0.03 \\
\hline
\end{tabular}

\section{CONCLUSIONS}

The accumulation of heavy metals in maize grown in the soil cocontaminated with $\mathrm{Cd}, \mathrm{Pb}$ and $\mathrm{Zn}$ depended on the type of soil. The plants accumulated more of all metals from the sandy soil compared with the loess. The smallest difference between the soils was found for $\mathrm{Cd}$.

Translocation of metals from the roots to the aerial parts of maize depended on the type of metal. The highest amounts of $\mathrm{Zn}$, and secondly of $\mathrm{Cd}$, were translocated to the aerial parts of plants meant for consumption by animals and people, while $\mathrm{Pb}$ remained mostly in the roots.

Organic matter had a large impact on the uptake of metals from the soil, as well as their distribution in the plant. On the soil with higher organic matter content, there was a decrease in the bio- accumulation of $\mathrm{Cd}$ and $\mathrm{Zn}$, and to a much lower extent of $\mathrm{Pb}$. At the same time, a higher content of organic matter in the soil facilitated the translocation of $\mathrm{Zn}$, and to a lesser extent, of $\mathrm{Cd}$ to the aerial part of maize.

Cultivation of maize in the soil poorly co-contaminated with $\mathrm{Cd}$, $\mathrm{Pb}$ and $\mathrm{Zn}$, regardless of its type, creates the danger of translocation of these metals to grains in the amounts exceeding the permitted levels laid down for food products. This also applies to $\mathrm{Pb}$, even though this metal was to the slightest degree accumulated in the plant and transported to the aerial parts.

The amounts of metals accumulated both in grains and corn cobs do not exclude the possibility of allocating these parts of the plants for animal feed.

\section{REFERENCES AND LEGAL ACTS}

ABOLLINO O., ACETO M., MALANDRINO M., SARZANINI C., MENTASTI E. 2003. Adsorption of heavy metals on Na-montmorillonite. Effect of $\mathrm{pH}$ and organic substances. Water Research 37: 1619-1627.

BRADL H.B. 2004. Adsorption of heavy metal ions on soils and soils constituents. Journal of Colloid and Interface Science 277: 1-18.

BURLÓ F., GUIJARRO I., CARBONELL-BARRACHINA A.A., VALERO D., MERTINEZ-SÁNCHEZ F. 1999. Arsenic Species: Effects on and Accumulation by Tomato Plants. Journal of Agricultural and Food Chemistry 47: 1247-1253.

CAO H., WANG J., ZHANG X. 2007. Ecotoxicity of Cadmium to Maize and Soybean Seedling in Black Soil. Chinese Geographical Science 17, 3: 270-274.

CUI Y., DONG Y., LI H., WANG Q. 2004. Effect of elemental sulphur on solubility of soil heavy metals and their uptake by maize. Environment International 30: 323-328.

DA CUNHA K.P.V., DO NASCIMENTO C.W.A. 2009. Silicon Effects on Metal Tolerance and Structural Changes in Maize (Zea mays L.) Grown on a Cadmium and Zinc Enriched Soil. Water Air Soil Pollution 197: 323-330.

FIGUEROA J.A.L., WROBEL K., AFTON S., CARUSO J.A., CORONA J.F.G., WROBEL K. 2008. Effect of some heavy metals and soil humic substances on the phytochelatin production in wild plants from silver mine areas of Guanajuato, Mexico. Chemosphere 70: 2084-2091.

JASIEWICZ C., MADEYSKI M., TARNAWSKI M., BARAN A. Zawartość metali ciężkich w biomasie kukurydzy pod wpływem dodatku osadu dennego do gleby. Materiały z II konferencji naukowej "Ekotoksykologia w ochronie środowiska", Szklarska Poręba 25-27 września 2008, 147-152.

KABATA-PENDIAS A., MOTOWICKA-TRELAK T., PIOTROWSKA T., TERELAK H., WITEK Y. 1993. Assessment of contamination level of soil and plants with heavy metals and sulphur. IUNG Puławy Publisher, P(53): 1-20 (in Polish).

KABATA-PENDIAS A. 2004. Soil-plant transfer of trace elements an environmental issue. Geoderma 122: 143-149.

KALBITZA K., WENNRICH U.R. 1998. Mobilization of heavy metals and arsenic in polluted wetland soils and its dependence on dissolved organic matter. The Science of the Total Environment 209, 1: 27-39.

KANG J., ZHANG Z., WANG J.J. 2011. Influence of humic substances on bioavailability of $\mathrm{Cu}$ and $\mathrm{Zn}$ during sewage sludge composting. Bioresource Technology 102: 8022-8026.

KARCZEWSKA A. 2008. Ochrona gleb i rekultywacja terenów zdegradowanych. Wydawnictwo Uniwersytetu Przyrodniczego we Wrocławiu, 235 
KUNGOLOS A., SAMARAS P., TSIRIDIS V., PETALA M., SAKELLAROPOULOS G. 2006. Bioavailability and Toxicity of Heavy Metals in the Presence of Natural Organic Matter. Journal of Environmental Science and Health Part A 41:1509-1517.

LAMELAS C., WILKINSON K.J., SLAVEYKOVA V.I. 2005. Influence of the composition of natural organic matter on $\mathrm{Pb}$ bioavailability to microalgae. Environmental Science Technology 39: 6109-6116.

LAVADO R.S. 2006. Concentration of potentially toxic elements in field crops grown near and far from cities of the Pampas (Argentina). Journal of Environmental Management 80: 116-119.

MACLEAN A.J. 1976. Cadmium in different plant species and its availability in soils as influenced by organic matter and additions of lime, P, Cd and Zn. Canadian Journal of Soil Science 56, 3: 129-138.

MARTÍNEZ C.E., MOTTO H.L. 2000. Solubility of lead, zinc and copper added to mineral soils. Environmental Pollution 107: 153-158.

PERALTA-VIDEA J.R., GARDEA-TORRESDEY J.L., GOMEZ E., TIEMANN K.J. PARSONS J.G., CARRILLO G. 2002. Effect of mixed cadmium, copper, nickel and zinc at different $\mathrm{pHs}$ upon alfalfa growth and heavy metal uptake. Environmental Pollution 119: 291-301.

Rozporządzenie Ministra Zdrowia z dnia 13 stycznia 2003 r. w sprawie maksymalnych poziomów zanieczyszczeń chemicznych i biologicznych, które mogą znajdować się w żywności, składnikach żywności, dozwolonych substancjach dodatkowych, substancjach pomagających w przetwarzaniu albo na powierzchni żywności. (Dz.U. 2003. $\mathrm{Nr}$ 37, poz. 326; zał. 1).

SEREGIN I.V., SHPIGUN L.K., IVANOV V.B. 2004. Distribution and Toxic Effects of Cadmium and Lead on Maize Roots. Russian Journal of Plant Physiology 51, 4: 525-533.
SEREGIN I.V., KOZHEVNIKOVA. 2005. Distribution of Cadmium, Lead, Nickel, and Strontium in Imbibing Maize Caryopses. Russian Journal of Plant Physiology 52, 4: 565-569.

SHANKER K., MISHRA S., SRIVASTAVA S., SRIVASTAVA R., DASS S., PRAKASH S., SRIVASTAVA M.M. 1996. Effect of Selenite and selenate on Plant Uptake of Cadmium by Maize (Zea mays). Bulletin Environmental Contamination Toxicology 56: 419-424.

SHAO G., CHEN M., WANG W., MOU R., ZHANG G. 2007. Iron nutrition affects cadmium accumulation and toxicity in rice plants. Plant Growth Regulation 53: 33-42.

SKŁODOWSKI P., MACIEJEWSKA A., KWIATKOWSKA J. 2006. The effect of organic master from brown coal on bioavailability of heavy metals in contaminated soils. Soil and Water Pollution Monitoring, Protection and Remediation. NATO Science Series IV. Earth and Environmental Sciences 69: 299-307.

SUTHAR V., MEMON K.S., MAHMOOD-UL-HASSAN M. 2014. EDTA-enhanced phytoremediation of contaminated calcareous soils: heavy metal bioavailability, extractability, and uptake by maize and sesbania. Environmental Monitoring and Assessment 186: 3957-3968.

SZABÓ G., CZELLÉR K. 2009. Examination of the heavy metal uptake of carrot (Daucus carota) in different soil types. AGD Landscape and Environment 3, 2: 56-70.

USA NRC. 2000. Nutrient Requirements of Beef Cattle: 7th Revised Edition. The National Academies Press, s.248.

WU J., WEST L.J., STEWART D.I. 2002. Effect of humic substances on $\mathrm{Cu}(\mathrm{II})$ solubility in kaolin-sand soil. Journal of Hazardous Materials 94, 3: 223-238.

ZHANG., DANG Z., ZHENG L.C., YI X.Y. 2009. Remediation of soil co-contaminated with pyrene and cadmium by growing maize (Zea mays L.). International Journal of Environmental Science 6, 2: 249-258. 